\title{
Empowering of Small -Micro and Medium Enterprises (SMMEs):
}

\section{A Case of Botswana}

\author{
Fridah Muriungi Mwobobia (Mrs) \\ Limkokwing University of Creative Technology- Botswana \\ Business \& Globalization Faculty \\ P.o Box 10313, Gaborone-Botswana \\ Tel: 267-72-259-682Ｅ-mail: joyfredahmuriungi@yahoo.com
}

Received: July 23, 2012

doi:10.5430/bmr.v1n4p88
Accepted: November 5, 2012

Online Published: November 20, 2012

\begin{abstract}
The study aimed to establish the economic empowerment schemes put in place by the Botswana Government to help the Small-Micro and Medium Enterprises (SMMEs). The objectives followed were to i) identify the types of SMMEs operating in Botswana ii) the main empowerment schemes put in place by the Botswana Government iii) the challenges faced in the process of implementing those schemes and the recommendations put forward. The study employed desktop research approach. Findings revealed that the Botswana Government has put in place powerful schemes such as CEDA, LEA, Youth Grant Fund, eYen and Young farmers CEDA fund among others. The challenges faced in implementing the schemes are among others; failure to repay, abandoning of the projects, duplication of effort due to lack of overall coordination by different stakeholders, limited resources and capacity etc. The study recommends further research especially on the accessibility of financial aid by SMMEs in Botswana.
\end{abstract}

Keywords: Small and Micro enterprises, Government economic empowerment, Botswana

\section{Introduction}

Small and Medium Enterprises (SMEs) play a crucial role towards achieving industrial and economic development objectives of an economy. While their diverse nature makes their actual contribution to the economy somewhat different, SMEs play an important role in employment creation, especially for the unskilled and semi-skilled. They also possess the potential as an engine of growth, it is therefore important to create a favourable environment that allows them to expand and prosper (LEA, 2007). This is also emphasized by Acquah \& Mosimanegape (2006) who argue that for most developing countries, Botswana inclusive, small business enterprises in the informal sector generate employment and incomes for their owners and operators hence reduction of poverty. Similarly, in Malaysia, Small and medium enterprises are playing an increasingly important role in sustaining economic growth and generating employment (Xavier, Perumal \& Mohan 2011). SME constitute the dominant form of business organization, accounting to over 95 percent and up to 99 percent of enterprises depending on the country. They are responsible for between 60-70percent net job creation in Organization For Economic Cooperation and Development (OECD) countries (Policy Brief, 2006).

To Ongori \& Migiro (2011) SMEs are considered as the source of breeding ground for entrepreneurs in developing and developed countries. SMEs are the key to a country's economic growth and their success can help reduce poverty, improve health of families and communities, raise literacy and educational levels, and empower women. It is therefore sound policy to support them (Commonwealth businesswomen, 2002).

In Botswana, it is said that SMMEs contribute 75 percent of formal sector employment (LEA, 2007) while in Kenya the sector contributed over 50 percent of new jobs created in the year 2005 (Economic Survey, 2006). To Sekwati (2010) SMMEs are seen as important drivers of industrialization. In addition, Mpolokeng (2009) emphasizes that Small and Micro Enterprises (SMEs) will be the key drivers of sustainable economic growth in Africa over the next 10 years. The Government of Botswana recognizes the importance of the informal sector/SMMEs to the country's economy (BIDPA, 2007). 
Pule (2009) adds that the Government is keen to have citizens in control of the dynamic sectors of the economy of Botswana and hence supports their training for such exercise. The Government has for a long time been emphasizing on the diversification of the economy and willing to give the necessary support (Bedia, 2006).

The Botswana Government acknowledges that whilst appropriate incentives must be provided to attract foreign capital, it is also necessary to ensure that local entrepreneurs are not disempowered in the process hence the formulation of Small, Medium and Micro Enterprises policy is to promote citizen entrepreneurship- SMMEs policy (Botswana Business Guide, 2004). Government continues to promote citizen economic empowerment by implementing programmes that enhance citizen participation in economic activities and business ventures (Botswana Budget speech, 2010). The achievement of good economic growth is anchored around an environment of well focused policies aimed at poverty eradication through the empowerment of the people by availing them of access to factors of production, particularly credit (Noruwa \& Emake 2012).

In addition Letsebe (2010) emphasizes that, foreign companies should not benefit from the country's national budget at the expense of Batswana. The Government must ensure that local companies benefit more from citizen economic empowerment schemes.

\subsection{Research Objectives}

This study purely seeks to find out:

i) The type of SMMEs operating in Botswana

ii) The main empowerment schemes put in place by the Government of Botswana

iii) Challenges facing the Botswana Government in pursuing such initiatives

iv) What can be recommended to the Botswana Government and other developing countries pursuing similar empowerment schemes?

\section{Methodology}

To meet the research objectives the study employed desktop research by reviewing relevant texts, websites, annual reports, journals, magazines and newspapers.

\section{Literature Review}

\subsection{Definition of small business}

A small business is an enterprise that is employing between 6 and 25 paid employees, and has an annual turnover of between p60,000 and 1,500,000 (Acquah \& Mosimanegape 2007). Mugwara (2000) defines small and micro enterprises as businesses owned by individual entrepreneur who employs one person to twenty people as the business grows. To Bowen, Morara \& Mureithi (2009) it can be inferred that small and micro businesses are dominated by people with relatively low levels of education.

Entrepreneurs are widely recognized as the prime movers of economic development; the people who translate ideas into action. An interesting though not widely accepted definition of an entrepreneur is a person who has the ability to scan and identify opportunities in his or her environment, gather the resources necessary to take advantage of the opportunities and implement successful action to utilize the opportunities.

\subsection{Types of SMMEs operating in Botswana}

There are three main legal forms for operating a business in Botswana:

i) The single owner enterprise

ii) The partnership and

iii) The private company ( Botswana Business Guide, 2003)

\subsubsection{The single owner enterprise}

This is a business run, owned and controlled by one person Wokorach (1997). The person who runs a business on his or her own account is known as the single owner or sole proprietor of the business. The sole owner of the business has great flexibility to run the business as he/she wishes however a single owner runs a risk because he/she is personally liable for all the debts and liabilities of the business (Botswana Business guide, 2003).

It is the simplest form of a business structure and operation, it has fewer formalities and a few legal restrictions (Malibala, 2012). 


\subsubsection{The partnership}

A partnership exists when two or more people agree to carry on a business together in order to make profit for their joint benefit. Each partner must contribute something such as money, work or property to the resources of the business. There must be an intention to make profit which is to be shared between partners. Partnership may have between 2-20 people. In partnership, business is run with simplicity and flexibility just as in sole proprietorship and has similar risks of limited liability (Botswana Business guide, 2003). According to Malibala (2012) there is pride of ownership which generates personal motivation and identification with the business. Combining energies and talents of the two or more partners can often be successful where one person alone would fail.

\subsubsection{The private company}

Wokorach (1997) defines a limited company as one whose financial liability is limited to the amount of money put by the shareholders. The vast majority of companies in Botswana are private companies limited by shares which are suitable for starting a business with fewer formalities. In most private companies the owner(s) of the business are both shareholders and directors of the company (Botswana Business guide, 2003).

According to Acquah \& Mosimanegape (2007) small business enterprises in Botswana fall in the following categories manufacturing /production 17.4 percent, trade 40.1 percent and services 42.5 percent.

According to the new SMMEs policy Micro-enterprises also referred to as informal sector enterprises, may employ up to six people, but they typically employ only one or two people including the owner and may even be part-time operations. They typically operate in an unstructured way usually from residential premises and lack formal registration and can have a turnover of up to P60,000. They are estimated to be to be around 50,000 micro-enterprises in Botswana and the majority are owned by women

(http://www.bidpa.bw/docs/bidpa_briefing/SPECIAL\%20BRIEFING\%20-\%20SME\%20POLICY).

Small enterprises operate in a more structured way, and may have links to medium or large firms as markets for their goods and services. They can have less than 25 employees and an annual turnover of between p60,000 and p1500 000. They are estimated to be around 6000 small enterprises in Botswana.

Medium enterprises have a more outward looking approach to marketing their products and may be involved in exporting and have links to larger firms, both of which present good opportunities for growth. They have between 25 and 100 employees and annual turnover of between P1.5 million and P5 million. They are estimated to be 400-500 medium size enterprises in Botswana (http://www.bidpa.bw/docs/bidpa_briefing/SPECIAL\%20BRIEFING\%20-\%20SME\%20POLICY).

\subsection{Empowerment Schemes put forward by the Botswana Government}

In the 1990s, there has been a new paradigm shift in development thinking. Empowerment has been at the centre of this paradigm shift and the attempt to re-conceptualize development and development strategies aimed at poverty alleviation, particularly in the rural areas. In line with this new thinking, the Human Development Report states that "development must be woven around people, not people around development - and it should empower individuals and groups, rather than dis-empower them" (UNDP 1993, Abdalla Gergis 1999). And this is what the Botswana Government is putting in place. Botswana seeks to diversify its economy away from minerals (The economic insight, 2010).

Unemployment remains a major challenge for the Botswana Government ( with unemployment national level of 24.6 percent in 2004, with younger people especially females worst affected 60.8 percent average in 15-29 and 45.5 percent average in 20-24 age range). Employment creation is limited by capital (Joint annual Report, 2006). It's due to such challenges, that Botswana Government feels it has an obligation to empower the disadvantaged hence the empowerment schemes.

The Minister of finance in Botswana was quoted saying "Government has no greater priority than empowering our future, by empowering the youth. This is the more reason why various programmes such as Youth Development Fund; Construction Industry Trust Fund; and Young Farmers Fund under CEDA, have been introduced to assist in creating more job opportunities, especially for the youth" (Botswana Budget speech, 2012).

In Botswana, economic empowerment has been understood to mean a set of policies or programs designed to benefit a specific segment of the society; the Batswana (Abdalla, 1993). The fundamental goal of empowerment is to help individuals within the society to improve the quality of their own lives and shares equitably in the benefits of economic growth. Growth that depends on constant infusions of grants or subsidized financing from government or other donors is inherently unsustainable. Start-up financing is viewed as one of the most important factors impacting 
entrepreneurial activity. Lack of access to finance is identified by the authors as one of the most significant barriers for the start-up and growth of small businesses. Start-up business support services aim to assist entrepreneurs to develop their ventures and to cope with inevitable challenges of the business and the environment (Lundstrom \& Stevenson 2005, Alpheus 2011). And that is why the Government of Botswana feels it, it should step in to empower the entrepreneurs.

In addition, financing is necessary to help SMEs operators to set up and expand their operations, develop new products and invest in new staff or production facilities. Many small businesses start out as an idea from one or two people, who invest their own money and probably turn to family and friends for financial help, in return for a share in the business. But even if they are successful, there comes a time for all developing SMES to need new investment to expand or innovate further. That is where they often run into problems, because they find it much harder than larger businesses to obtain financing from banks, capital markets or other suppliers of credit (Policy Brief, 2006). The Economic diversification is a key policy drive for the Government of Botswana, one key area of the policy concern is the enhancement of the performance of small and micro-enterprises SMEs (Okurut, olalekan \& Mangadi, 2006). Governments at various levels can support and facilitate opportunity exploitation by making the business environment conducive or attractive for starting and growing business ventures Alpheus(2011). Infrastructure strategy is normally provided by the government in assisting SMEs by offering them subsidies and encouraging ICTs providers to have special discounts for SMEs thus reducing costs (Ongori \& Migori, 2011).

In order to empower the entrepreneurs Botswana Government has put the following schemes in place:

i) Citizen Entrepreneurial Development Agency (CEDA)

ii) Local Enterprise Authority (LEA)

iii) Youth Grant Fund

iv) e-innovation Youth Empowerment Programme (e-YEP)

v) Young farmers ceda fund

\subsection{Citizen Entrepreneurial Development Agency (CEDA)}

Citizen Entrepreneurial Development Agency (CEDA) is the Government's most recent development finance institution, which provides subsidized credit, along with monitoring, mentoring, business advisory services and training, to selected citizen entrepreneurs (Okurut, olalekan \& Mangadi, 2006). Government offers funding, training and mentoring services to Batswana wishing to go into business or to expand existing businesses through Citizen Entrepreneurial Development Agency (Botswana Budget speech, 2010).

The Citizen Entrepreneurial Development Agency provides a holistic approach to the development and promotion of viable sustainable citizen-owned enterprises. This is done through the provision of financial assistance in the form of loans at subsidized interest rates, and back-up business training and mentoring services to enhance the sustainability of these enterprises. According to Moseki (2009) CEDA is the only institution that gives a loan without security and it is the Government's citizen economic empowerment arm. CEDA finances projects that the commercial banks considers risky to fund, because its aim is to help Batswana out of poverty and assist them to take part in the economy taking them away from being spectators (Keakabetse, 2012).

CEDA lends from P500 to P150 000 at 5 percent interest per annum payable over a period of five (5) years for the small scale category of enterprises. Repayment periods vary according to the size of the loan and the project cash flow. The smaller the loan amount, the shorter is the repayment period. The maximum repayment period is 60 months or 5 years, with some flexibility for projects of a special nature in sectors such as agriculture. There is a grace period on the repayment of the loan, which varies depending on the implementation schedule and gestation period of the project. From P150 001 to P2 million at 7.5 per cent interest per annum payable over a period of 7 years for medium scale enterprises (Ceda annual report, 2008).

A Venture Capital fund has recently been established that is intended to facilitate funding of projects that could be both locally and foreign owned (http://www.gov.bw/en/Business). This is provided under the Ceda Venture Capital Fund(CVCF).However, promoters are required to contribute a minimum of 25 percent of total project cost as equity and pay market related interest rates.

In CEDA's $3^{\text {rd }}$ strategic plan of 2009-2012 the agency, has revised limits for loans of P4 million, up from one million and up to P30 million in the venture capital product, the interests have been reviewed charging 5 percent per annum for loans below one million pula and seven percent for loans above that, in addition CEDA has revised its repayment periods to 15 years from seven years and consolidated its various product offerings under a one-stop shop model. 
The CEDA venture Capital Fund and Credit Guarantee Scheme have been brought back into the Agency's ambit, eliminating the need for clients to run around for assistance (Moseki, 2009).

The Agency has also introduced new products such as debt and equity financing, credit guarantee for short and long term, letters of credit/performance bonds, and a citizen Entrepreneur Mortgage Assistance Equity Fund(CEMAEF) among others. CEDA has also introduced an invoice discount /factoring product aimed at helping the cash flow of citizens -run businesses CEDA has also appointed a firm of independent consultants to tackle the contentious issue of rejected applications, as some of these applicants have previously accused the Agency of lacking capacity to understand all business proposals (Moseki, 2009).

The scheme is available for: citizens of 18 years or over wishing to start a legal business, existing legal businesses that are owned by citizens of 18 years of age and above; and under the Venture Capital Fund, both citizens and joint ventures between citizens and foreign investors.

CEDA requires a framework of specific requirements from citizens accessing the loan funds from the institution; committed entrepreneur with a viable and sustainable business idea, a detailed business proposal, security (all assets financed by CEDA) are automatically used as security. In addition, where there are no fixed assets funded by CEDA or CEDA funded assets do not provide adequate security, promoters are required to pledge other properties or assets as security or to sign personal guarantees or sureties in lieu of such securities, licenses: Promoters are required to secure the necessary licenses and permissions for the proposed project as required by law, premises, promoters are required to secure necessary land and premises from which the project is to operate. Evaluation of proposals, agreements, promoters of approved projects are required to sign a loan or shareholders agreement with CEDA after having met all conditions of approval, compulsory reporting: regular reports are required of all approved projects. The reports are to be produced for the duration of the loan to a standard acceptable by CEDA as may be determined by the CEDA Board from time to time, depending on the nature of the project. The cost of the reports shall be borne by the promoter, willingness to be guided, number of loans: Successful applicants are not given more than one loan at a time and eligibility for a further loan is dependent on the successful retirement of the initial loan and the performance of the project financed, except in some cases (Ceda customer charter, 2006).

\subsection{Local Enterprise Authority (LEA)}

The Local Enterprise Authority (LEA) was established by the Small Business Act, Number 7 of 2004 as a Statutory Authority of the Government of Botswana. The Authority is guided by a Board of Directors drawn from both the Private sector and the Public sector, and is headed by a Chief Executive Officer. The main objective was to promote as well as to facilitate entrepreneurship and enterprise development among the Small, Medium and Micro enterprises (SMMEs) community in Botswana thus creating vibrant SMMEs in the country. LEA's vision is 'to be the centre of excellence for entrepreneurship and sustainable SMME development in Botswana' and the mission is 'to promote and facilitate entrepreneurship and SMME development in pursuit of economic diversification' (LEA, 2008).

LEA is a co-ordinated and focused one-stop shop Authority that provides development and support services to the local industry needs of SMMEs, encompassing training, mentoring, business plan finalization, market access facilitation, and facilitation of technology adaptation and adoption. LEA was established mainly because the Government realized that without such an organ, its efforts of empowering Batswana to become better entrepreneurs would continue to hit a snag (http://www.lea.co.bw/uploads/files/spotlight_on_lea.pdf?size=665298).

LEA is the government's last throw of the dice in its efforts to bring life to the potential of the small, medium and micro businesses in Botswana which over the years, have struggled unsuccessfully to add value to the national economy, Local Enterprise Authority (LEA) was established when Government realized that the road to developing a thriving SMME (Small Medium and Micro Enterprise) sector had been a very bumpy ride over the years (Matome, 2007).

The Authority's key sectors are manufacturing, tourism, agriculture, and any services that support the three business sectors. In particular, LEA targets women, youth, and the unemployed. Part of the strategy is to encourage businesses to use locally available natural resources and raw materials, within the identified sectors. Also the Authority endeavors to build competencies in quality and efficiency, and to encourage import substitution and export oriented products and services.

In order to encourage the spirit of entrepreneurship and enterprise in Botswana, LEA offers highly specialized development and support services which include but are not limited to the following:

- Facilitation of business planning 
- Providing training, mentoring and advisory services

- Identifying business opportunities for existing and future SMMEs

- Promoting domestic and international linkages

- Facilitating access to markets

- Facilitating exploitation of government and large firms' procurement opportunities by SMMEs

- Facilitating access to finance

- Facilitating technology adoption and diffusion

- Promoting general entrepreneurship and SMME awareness

LEA does not provide finance to entrepreneurs. However the Authority facilitates access to finance as well as provides support services to SMMEs, before and after funding. Efforts continue to be made by the Authority to engage various stakeholders in the Financial Services industry, including commercial banks, to work together in the development and support of the SMME sector in the country ( LEA, 2008).

LEA has thirteen branches found in: Gaborone, Francistown, Selebi-Phikwe, Serowe, Molepolole, Mochudi, Maun, Masunga, Kasane, Ghanzi, Tsabong, Ramotswa, and Kanye. The opening of these branches is to make it easy for people wanting to start businesses. It also helps with the marketing of SMME products and services (http://www.lea.co.bw/uploads/files/spotlight_on_lea.pdf?size=665298).

LEA in conjunction with the Government of Botswana has empowered the SMMEs owners by helping them on tendering procedures. This has been done through a series of workshops throughout the country which have emphasized on the need by small business owners to familiarize themselves with tender documents. In addition LEA refers some of its clients to accredited business development service providers for further assistance in terms of business planning writing, market research, costing and pricing, financial projections and record keeping (Masolotate, 2012).

LEA has a virtual office where anyone could just dial the toll free number at no charge, and make enquiries about LEA's services. The virtual office, which is open to all citizens across the country, is located in Mochudi and is managed by a team of four, including a team leader and business and marketing advisors, all extremely knowledgeable in their field of business.

LEA is also seeking to develop a breed of sustainable and profitable SMMEs through the concept of incubation. Through this concept, LEA shall allocate factory shells, and offices to certain businesses, that will then be mentored and monitored for a period of three to five years. When the businesses have matured enough to sustain themselves and compete effectively in the market they will be required to move out and be own their own. The units in Pilane near Mochudi, Gaborone, and Francistown, will now be used to incubate the various prospective Batswana businesses. This LEA incubation system would be unique in that the SMMEs would continue to receive assistance, and monitoring, as well as skills development, to ensure the efforts bear fruit (LEA,2008).

LEA in conjunction with First National Bank of Botswana (FNBB), University of Botswana and Sunday standard Newspaper launched Itsose Business competition in which entrepreneurs are requested to prepare business plans and present them to the judges, then the top 100 finalists are trained on how to prepare proper business plan. The main aim is to equip potential entrepreneurs with skills. Out of 100, 10 winners are expected to receive funding from FNBB and get non financial assistance from LEA (Sunday standard, 2009).

\subsection{Youth Grant Fund}

The Ministry of Youth, Sport and Culture has the portfolio responsibility among others for the coordination, implementation and evaluation of the National Youth Policy. In implementing the National Youth Policy the Ministry, has put in place a Youth Development Fund aimed at empowering youth to own businesses and create sustainable employment opportunities for young people through the development of sustainable projects. It caters for out-of-school youth, marginalized youth, unemployed youth and underemployed youth (working youth earning less than P600 monthly) who are citizens of Botswana aged between 18-29 years (Molelu, 2010).

The Ministry with the assistance of the Botswana National Youth Council, are the leading partners in youth development. The major functions of the Youth Division are as follows:

- To develop and review policy in all matters related to youth affairs

- To implement and monitor youth programmes and initiatives 
- To initiate research and keep up to date information relating to youth issues

- To promote collaborative efforts between all youth NGOs and the Government of Botswana, and any other relevant stakeholders

- To promote collaborative efforts within relevant Government Ministries

(http://www.mysc.gov.bw/youth/index.php/programmes-youth).

The Youth Development Fund is 50 percent grant and 50 percent interest free loan of the total approved amount. The funding ceiling is P100, 000. Beneficiaries can benefit only once under the fund and are expected to graduate and utilize other financial intermediaries to expand and grow their establishments. Projects funded are divided into four categories namely: tourism, agriculture, services and manufacturing (Molelu, 2010).

The repayment periods for the loan component is as follows: Up to P25 000 shall not exceed 36 months, from P25 001 to P50 000 shall not exceed 60 months, the grace period for the loan component shall not exceed 12 months and shall be as follows: Non-agricultural projects -3 months, Poultry, Beekeeping, Fish Farming, Rabbits, Horticulture -6 Months Small Stock, Piggery - 12 months and Livestock, Horses, Donkeys, Dog Breeding - 12 months ( Youth Economic Empowerment, 2010).

By 2010, about 632 beneficiaries of YDF had been provided with mentoring and business skills training (BOPA, 2010).

\section{7 e-innovation Youth Empowerment Programme (eYEP)}

This is another youth scheme under Ministry of Youth, Sport and Culture. The e-innovation Youth Empowerment Programme (eYEP) is a programme where the young people and graduates between 18-35 years are in invited to submit feasible business proposals in the Information and Communication Technology and Science and Technology sectors. There is substantial focus on creativity, innovation, social responsibility and sustainability of the project. Financial assistance provided by the eYEP is in the form of a grant. The financial assistance may be used for infrastructural developments such as movable containers, etc required for the project or to cover working capital or both, provided that the requested amount falls within the fund ceiling projects (Youth Economic Empowerment, 2010).

The Programme ceiling is P145 000.00 which is 100 percent grant and beneficiaries can only benefit once under the Programme. The expectation is that they have to graduate and utilize other financial intermediaries to expand and grow their establishments. Since the Government wants to encourage innovation, creativity and uniqueness business proposals with, but not limited to the following as core services or products are encouraged : Internet café, Secretarial services, Computer Hardware and Software retail, Local Area Network Installation, Graphics design and printing focused on corporate Identity and Advertising and promotional materials ( e-innovation Youth Empowerment programme, 2009).

The programme has the following objectives:

- To promote creativity and innovation among the youth

- To promote entrepreneurship amongst the young people in Botswana

- To increase usage of ICT by the public

- To empower youth

- Economic diversification materials ( e-innovation Youth Empowerment programme, 2009).

3.8 Young farmers ceda fund

CEDA, upon realizing that the sector is dominated by the elderly, decided to come up with a program called Young Farmers Fund with a view to encourage youth to participate in the agriculture sector. It is expected that as young people they would adopt modern technologies of farming and improve the sector's output (Mogwebi, 2010).

The Fund is available to all young people (aged between 18 and 35 years) who are citizens of Botswana or wholly citizen owned companies, wishing to start or expand agricultural projects. Botswana's population is predominately young, according to the 2001 population census, young people of the age group 0-29 constituted 67.5 percent of the total population of Botswana. The Household Income and Expenditure survey of 2002/03 revealed that youth unemployment rate is highest among the group of 15 to 29 years. It is against this background that His Excellency the President then, in the State of the Nation Address in November 2005, announced the need to create a fund under CEDA to provide agricultural loans for graduates (degree, diploma and certificate holders) from agricultural training institutions and thus further add impetus to efforts to tackle youth unemployment (Ministry of finance and Development planning, 2006). 
The Fund is available to Batswana aged 18-40, after the age ceiling of 35 was found limiting other eligible young citizens. In addition, CEDA has also categorized any inexperienced farmers regardless of their age to be assisted under Young Farmers Fund (Mogwebi, 2010).

Through the Young Farmers Fund (YFF), as the Fund is called, young people will have improved access to finance and entrepreneurial training and thus will be able to engage in sustainable agricultural activities better equipped with the requisite skills for running farming businesses.

The major objectives of the young farmers fund are to:

- Foster youth enterprises in agriculture through effective pursuit of opportunities in the agricultural sector

- Encourage the development of competitive and sustainable youth enterprises by rewarding competitiveness and discouraging inefficiency

- Create sustainable employment opportunities for young people through the development of sustainable agricultural projects. Agriculture and microenterprises contribute immensely to job creation (Noruwa and Emake, 2012)

- Promote the development of vertical integration and horizontal linkages between enterprises and primary industries in agriculture.

- Minimize migration of young people to urban centres through creation of job opportunities in rural areas (Ministry of finance and Development planning, 2006).

The maximum size of the loan for a project is P500 000 with an interest rate of 5 percent. The repayment periods for loans are as follows; up to P100 000 will not exceed 60 months, from P100 001 to P250 000 will not exceed 84 months, and above P250 000 will not exceed 120 months. The grace period for loans will not exceed 24 months and the interest accruing during the grace period will be capitalized. (http://www.ceda.co.bw/uploads/files/yff_guidlines.pdf)

By 2012, about 367 youths had benefited form the fund which had disbursed over P142 million (BOPA, 2010).

\section{Challenges faced by the Botswana Government $t$ in the process of empowering the SMMEs}

In pursuance of these empowerment schemes the implementers have faced the following challenges:

i. The global recession, which did not leave Botswana unscathed, resulted in a decline in operating revenue for CEDA and its subsidiaries, which saw significant under performance of CEDA funded projects which contributed to have a negative impact on the collections. CEDA Venture Capital Fund (CVCF) recorded a loss of P53 million and had to write down investments made through CVCF by P30 million. It further raised provisions for bad and doubtful debts of P40 million against the development fund (Mogwebi, 2010).

ii. Failure to service their loans, entrepreneurs fail to make loan repayments as expected. The minister of youth, sport and culture was quoted to say 'the Batswana have the culture of entitlement to the extent that they fail to pay loans from commercial banks (Ntshole, 2012).

iii. Delay in supplying the equipment needed for the approved businesses, led the business not to start operating as expected.

iv. Continuous assessment of the projects in order to see how the business is doing and how best to assist towards self sustainability is a challenge due to shortage of personnel (Modikwa, 2012).

v. Several challenges facing the commercial pig operations in Botswana include the outbreak of Foot and Mouth Disease (FMD), high feed prices, inadequate slaughtering facilities, unorganized marketing, poor breeding stock, transboundary diseases and inadequate extension service and this leads to project failure hence the entrepreneur inability to repay the loan (Montsho \& Moreki 2012). The outbreak of FMD in okavango in was a setback, as it adversely affected the implementation of cattle farming projects for CEDA Development Fund and the Young Farmers Fund in terms of loan repayment and further funding of such projects in the area (CEDA Annual report, 2008).

vi. Weak linkages among major stakeholders. There is no collaborative effort among the main stakeholders such as LEA, CEDA, MoA and Depart of Culture and Youth (Galeboe et al., 2009, Montsho etal 2012) who provide training, mentoring and coaching services.

vii. Abuse of programme funds, some beneficiaries took advantage of lack of knowledge or ignorance from their fellow group members and used the funds for their personal benefit (Molefi, 2012). 
viii. Lack of overall coordination by different stakeholders to draw initiatives together and make sure they are complementary, characterized by significant overlap/duplication between the various institutions, with each of them operating in isolation and not coming together to discuss issues of common interest ( LEA Report, 2009).

ix. LEA has a limited resource allocation compared to the large scope of its mandate there is recognition within LEA that not all business advisors are currently sufficiently capacitated to diagnose advanced BDS needs and both SMMEs and BDS providers have raised concerns regarding LEA's speed of service, processing times and systems, in relation to speed of client registration and BDS accreditation, as well as insufficient notice to BDS providers for delivery of services (LEA report, 2009). This is also faced by CEDA's training and mentoring department in that 'there is still a challenge of securing experienced mentors across all sectors, which has to some extent impacted on performance of projects (CEDA Annual Report, 2008).

x. Monitoring and evaluation systems for key performance indicators across LEA's service offerings are nonfunctional optimally, including information flows between LEA branches and headquarters (LEA Report, 2009).

xi. LEA's current client base and database is very wide, with many inactive clients hence the inability to serve them (LEA Report, 2009).

xii. LEA has been low entrepreneurial spirit and talent, which means they have done more hand-holding for some aspiring entrepreneurs.

xiii. Lack of seriousness as entrepreneurs ventured into business because they could not find a job, that problem is rampant among the youth and noted that some leave their projects when they secure scholarship opportunities or find employment (BOPA, 2011). Chikumbudzi (2012) adds that projects fail due to mismanagement because of lack of commitment from the beneficiaries.

xiv. Youth's lack of drive in the agricultural sector, despite Government's efforts to pump millions into the Ceda young farmers fund, it has emerged that a lot of young farmers have not embraced the fund as vigorously as anticipated to ensure that it survives (Sunday standard, 2010). In addition Ceda young farmers fund faces collapse because the youth do not appreciate it much (Regonamanye, 2010).

\section{Recommendations}

Based on the findings this study recommends the following;

i. The loans grace period to be increased possibly to two years or more if possible.

ii. The Government should have a sustainable plan for the schemes which includes a business component to train the youth to sustain themselves through funds access. More efforts should be directed to public education (CEDA Annual Report, 2008).

iii. Review of the funding regulations should be done because some clauses in the memorandum are difficult to follow (Ntshole, 2012).

iv. Youth should be innovative to come up with original business ideas instead of copying business ideas that they may not be able to execute. This can be facilitated by proper exposure of the youth to variety of projects (Regonamanye, 2010).

v. Street children should be included in the programme because their number seems to increase due to the relocation of squatters which left some of them loitering in the streets and some even abandoned schooling as they had nowhere to go when their parents dispersed the district (Mbaeva, 2012).

vi. Flea markets should be organized often to give entrepreneurs opportunity to network. This will give small business community chance to interact with customers and get feedback on how best they improve their products (Mmolai, 2012).

vii. There is need for MOA, LEA, CEDA and Department of Culture and Youth to collaborate since they offer the same services to entrepreneurs.

viii. Extensive research should be conducted to develop programmes that are consistent with production and service systems practiced in the country.

ix. Firms must be oriented on ways of minimizing default rates. This can be done through among others, induction by organizations such as the Local Enterprise Authority (LEA) at a minimal cost.

$\mathrm{x}$. Clearly define the roles of all the different stakeholders in the empowering process to avoid repetition 
xi. Internal capacity building for LEA advisors (especially in advanced BDS).

xii. Focus on quality of clients and service to them, rather than numbers - reduce total number of LEA clients.

xiii. Enhance the culture of entrepreneurship in the country for this could lead to a transformed and wealthy society, where instead of seeking jobs people should be thinking of ways to create jobs (Lesemela, 2012).

\section{Further Research}

Based on the findings of this research, further research is recommended in this area especially on the accessibility of the finance by the SMMEs in Botswana.

\section{References}

Acquah, K. B, Mosimanegape, B. (2007). Factors contributing to the performance of Small Business enterprises in Botswana: A case study of Gaborone and Environs. A paper presented at the National Conference on the Informal Sector, GICC, Gaborone, Botswana.

Ahmad,S.Z.,Xavier, S.R.,Perumal.S.,Nor., M.L., \& Mohan,C.,J. (2011). The transition from Corporate Careers to business ownership: The case for women entrepreneurs in Malaysia. International Journal of Business Administration vol.2, No.3, 2011. http://dx.doi.org/10.5430/ijba. V2n3p 148

Amyx,C. (2005). Small Business challenges- The perception problem: Size Doesn't matter. Washington Business Journal.

BOPA. (2010). Alcohol levy benefits youth. Gaborone.

Botswana Business Guide. (2003). A comprehensive Guide to Doing Business in Botswana. Gaborone.

Botswana Local Enterprises Authority Report. (2009). Needs Assessment for SMMEs sector and Business Services providers.

Botswana Press Agency. (2011). Local Enterprise Authority creates jobs. Gaborone.

BIDPA. (2007). 'The role of the informal sector in Diversification of Selebi-Phikwe'. Gaborone.

BIDPA. (2007). Newsletter. Gaborone.

CEDA. (2007). Annual Report. Gaborone.

CEDA. (2008). Annual Report. Gaborone.

Chikumbudzi, L. (2012). Collapse of youth projects worries cllrs. DailyNews: Wednesday. August 29.2012no. 163.pg2.

e-innovation Youth Empowerment Programme. (2010). Gaborone.

Gary D,. Phillip C. and Joan A. (1998). 'Strategic performance model', Empowerment in organizations. Vol.6 no.2,1998. http://dx.doi.org/10.1108/14634449810210742

Gergis, A. (1999). Citizen Economic Empowerment In Botswana: Concepts and Principles BIDPA working paper No.22.

Jaiyeoba, O. (2010). The Impact of market orientation on SMMEs in the developing economies: a case of Botswana. International Journal of Business Administration. http://dx.doi.org/10.5430/ijba.v2n3p132

Joint Annual report. (2006). Republic of Botswana and European community.

Keakabetse,B. (2012). CEDA to fund small business. Mmegionline, Friday 13 July.

Kinyanjui, M.N. (2006). "Overcoming barriers to Enterprise Growth: The experience of MSEs in Rural Central Kenya" Nairobi, Kenya.

LEA. (2008). About Local Enterprise Authority; Gaborone.

LEA. (2007). First Hand Biz Information. Issue Two 24-30

LEA. (2007). Small, Medium and Large Enterprises Database, sector mapping and validation in Botswana: Findings and Strategies for Local Enterprise Botswana.

Malibala, K. (2012). 'Legal forms of a business structure', DailyNews , June 25, 2012 no. 119 pg 19.

Masolotate, B. (2012). 'LEA refers entrepreneurs', DailyNews, September 17, 2012 n0.176 p pg 6.

Mbaeva ,S. (2012). 'No sustainability plan for youth empowerment' Mmegi, Friday 29 June vol 29.No 97. 
Ministry of Finance and Development planning. (2006). CEDA young farmers Fund guidelines

Modikwa, O. (2012). 'Budding businesswoman praises poverty eradication programme', Mmegi Friday $29^{\text {th }}$ June, vol 29.no 97.

Mogwebi. (2012). 'The official Newsletter of the citizen Entrepreneurial Development Agency. ${ }^{\text {st }}$ Issue, March.

Molefi ,A. (2012). 'Some beneficiaries abuse programme', DailyNews, July 9, 2012 No.128, page 19.

Molelu, K. (2010). Youth success through fund.

Mmolai, E. (2012). 'Small entrepreneurs network', DailyNews, July 5, 2012 no.126 pg7

Montsho, T., \& Moreki, J.C. (2012). Challenges in commercial pig production in Botswana, Journal of Agricultural Technology. Vol.8 (4)1161-1170.

Mugwara, D. (2000). Small and medium enterprise policy \& strategy: Ministry of Industry \& Commerce.

Lesemela, K. (2012). 'Citizens urged to develop an entrepreneurial spirit', Mmegi Friday, 31 Aug,vol 29.

Noruwa,I.A., \& Emake,J.E. (2012). The role and sustainability of microfinance banks in reducing poverty and Development of Entrepreneurship in urban and rural areas in Nigeria. International Journal of Business Administration vol.3 , No.3, 2012, http://dx.doi.org/10.5430/ ijba.v3n3p33.

Ongori, H., \& Migiro S.O. (2011). Enhancing SMEs competitiveness: The strategies to resolve Barriers to information communication technologies adopted by SMEs. A paper presented in 2011 International Conference on Innovation and Growth: University of Botwsana.

Regonamanye,J. (2010). CEDA young farmers fund collapses?

Sekwati.L. (2010). Botswana: A Note on Economic Diversification. University of Botswana.

Shekari H., Rabiee.A.,Afshari M and Ahanim. (2011). Using effective factors in Employees Empowerment of industrial organizations with Analytical Network Approach (ANP) Case study: Textile factories of Qom province. International Journal of Business Administration.doi:10:5430/ijba.v2n3p160

Smith,B. (1997). Empowerment the challenge is now, Empowerment Organizations Journal, Vol.5, No.3, http://dx.doi.org/10.1108/14634449710180008

Youth Economic Empowerment. (2010).

[Online] Available: http://www.bidpa.bw/docs/bidpa_briefing/SPECIAL\%20BRIEFING\%20-\%20SME\%20POLICY.PDF-accesed on $22 / 6 / 12$

[Online] Available: http://www.lea.co.bw/article.php?id_mnu=20- accessed 29/6/12

[Online] Available: http://www.lea.co.bw/market_news/article.php?NewsID=22- 25/5/12

[Online] Available: http://www.ceda.co.bw/upload/Guidelines\%20Ceda.pdf- accessed 5/7/12

[Online] Available: http://www.lea.co.bw/article.php?id_mnu=21- Accessed 11/7/12

[Online] Available: http://www.gov.bw/Global/MYSC/MYSC_Youth_e-nnovation_Application_Guidelines.pdf $11 / 7 / 12$ 